УДК 342.9

DOI https://doi.org/10.32837/pyuv.v2i4(29).463

\author{
А.В. Шевченко \\ orcid.org/0000-0002-6962-3375

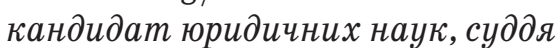 \\ Київського окружного адміністративного суду
}

\title{
ПРАВОВИЙ СТАТУС ПРАЦІВНИКІВ АПАРАТУ СУДУ
}

Вступ. У XXI столітті перед Україною постала проблема трансформування вкрай забюрократизованої та централізованої адміністративної системи державної служби в судовій системі. Необхідність здійснення ряду фундаментальних реформ задля покращення функціонування інституту державної служби і стабілізації політичних установ та створення сприятливих законодавчих умов для росту та економічного розвитку спонукала до реформування системи державного управління. Сьогодні наша держава декларує статус європейської, демократичної та правової держави. Про це свідчить ряд прийнятих державних стратегій, зокрема оновлення законодавства про державну службу. Необхідність реформування діючого законодавства про державну службу зумовлена також потребами в розмежуванні політичних та адміністративних посад, у врегулюванні правового статусу державного службовця і конкурсних процедур добору на посади вищого корпусу державної служби, у забезпеченні рівного доступу до державної служби, у наданні пріоритету кар'єрній службі, у створенні умов прозорої діяльності державних органів та гідної оплати праці державних службовців на основі обгрунтованої моделі з мінімальним впливом суб’єктивізму та проходженням служби виключно на основі особистих якостей.

Аналіз останніх досліджень і публікацій. Особливості та специфіку законодавства про державну службу досліджували такі науковці, як В. Аверя'нов, В. Тимощук, О. Курінний. У вітчизняній правовій доктрині продовжуються наукові пошуки щодо поняття і особливостей правового статусу різних суб'єктів права - одноособових та колегіальних (посадової особи, адвоката, прокурора, судді, а також Верховного Суду, Конституційного Суду України та ін.). Досліджувався правовий статус осіб, які займають адміністративні посади у судовій системі України. Однак правовий статус працівників апарату суду ще не був предметом спеціального дослідження як комплексна фундаментальна проблема в юридичній науці.

Формулювання цілей статті (постановка завдання). Оскільки працівники апарату суду в Україні є державними службовцями, то, безперечно, необхідно висвітлити особливості впливу нового законодавства про державну службу на працівників апарату суду, адже у цій сфері є певні невизначеності. Проаналізувавши положення за- конодавства про державну службу, слід звернути увагу на принципово нові підходи щодо визначення сфери дії законодавства про державну службу на прикладі його застосування до працівників апаратів суду загальної юрисдикції. Зокрема, це стосується порядку організації роботи державного службовця в судах, умов оплати праці, преміювання та заохочення, підстав та механізму звільнення державного службовця з посади, дисциплінарної та матеріальної відповідальності.

Виклад основного матеріалу. Судді є головними, але не єдиними суб'єктами владних повноважень, які здійснюють адміністративно-правове забезпечення функціонування судової влади. Навпаки, судді здійснюють судочинство, а забезпечення їхньої діяльності здійснюють численні суб'єкти публічної адміністрації. Діяльність зазначених осіб спрямована на те, щоб забезпечити для суддів усі умови для ефективного здійснення правосуддя, унеможливити будь-який негативний вплив на них. Серед численних суб'єктів публічної адміністрації, які здійснюють адміністративно-правове забезпечення судочинства, основне місце належить апарату суду. На думку Ю. Юрченко, апарат суду - це суб'єкти публічної адміністрації, державні службовці, які здійснюють свою діяльність згідно із Законом України «Про судоустрій та статус суддів» і відповідно до Закону України «Про державну службу». Вони разом 3 іншими суб'єктами публічної адміністрації забезпечують право фізичних і юридичних осіб на справедливе й гуманне адміністративне судочинство, однак не безпосередньо, а шляхом забезпечення суддям умов для ефективного здійснення судочинства $[1$, с. 56]. Закон України «Про судоустрій і статус суддів» визначив, що організаційне забезпечення роботи суду здійснює його апарат, який очолює керівник апарату (ст. 155) [2].

Однак, попри класичну практику дослідження правового статусу на прикладі однотипних органів чи інституцій, зазначимо, що правовий статус службовців апарату суду дійсно має свої особливості і є надзвичайно складним предметом для наукового дослідження, адже апарат суду складається з різних категорій працівників, тому визначити головні елементи їх загального правового статусу - це складне завдання.

Правовий статус працівників апарату суду визначається Законом України «Про державну 
службу» [3] з урахуванням особливостей, визначених спеціальним законом. Працівників апарату суду залежно від місця у процесі підготовки і умов для здійснення правосуддя можна поділяти на: а) керівництво (керівники апарату суду та його заступники); б) спеціалістів (консультанти, секретарі судового засідання, помічники суддів, судові розпорядники); в) технічний персонал (діловоди, оператори комп'ютерного набору, архіваріуси, завідувачі господарством, бібліотекарі та ін.); г) обслуговуючий персонал (водії, прибиральниці, робітники з обслуговування будівлі, двірники) [4, с. 67-68].

Під час дослідження зазначеного питання основну увагу варто приділити керівнику апарату суду. В організаційному забезпеченні діяльності судів основне значення має управління матеріально-технічними, фінансовими та бюджетними ресурсами для судової влади. Відповідно до ч. 1 ст. 155 Закону України «Про судоустрій і статус суддів» управління апаратом суду, а отже, ресурсами, які наявні в його віданні, виконує його керівник. Правовий статус керівника апарату суду $€$ багатогранним, оскільки різноплановість його повноважень вимагає від нього знань у багатьох сферах суспільної діяльності та досвіду управління. Результатом діяльності керівника має бути ефективне та своєчасне виконання завдань апарату суду. Законом України «Про судоустрій і статус суддів» встановлено, що керівник апарату суду очолює апарат та несе персональну відповідальність за належне організаційне забезпечення суду, суддів та судового процесу, відповідає за функціонування Єдиної судової інформаційної (автоматизованої) системи, інформує збори суддів про свою діяльність, а також призначає на посаду та звільняє з посади працівників апарату суду, застосовує до них заохочення та накладає дисциплінарні стягнення (ч. 3, 5 ст. 155) [2]. У наступній нормі згаданого вище Закону ідеться про особливий статус керівника апарату Верховного Суду та його заступників, які очолюють структурні підрозділи апарату Верховного Суду та відповідають за організаційне забезпечення діяльності касаційних судів. Основними завданнями керівника апарату суду є такі: здійснення безпосереднього керівництва апаратом суду; належне організаційне забезпечення суду, суддів і судового процесу; організація матеріально-технічного та соціального забезпечення суддів і працівників апарату суду; забезпечення функціонування автоматизованої системи документообігу суду; забезпечення організованості та злагодженості в роботі структурних підрозділів апарату, їх взаємодії у виконанні завдань щодо організаційного забезпечення суду [2].

Для виконання покладених на нього завдань керівник апарату суду зобов' язаний здійснювати такі дії: організовувати діяльність апарату, забезпечува- ти виконання його завдань; уживати заходів щодо вдосконалення та підвищення ефективності роботи апарату суду; подавати на розгляд суду пропозиції щодо структури, чисельності та штатного розпису апарату суду України; вносити на розгляд суду подання про відзначення працівників апарату; організовувати роботу атестаційної комісії та проведення щорічного оцінювання виконання державними службовцями апарату покладених на них обов'язків і завдань; формувати кадровий резерв апарату, забезпечувати організацію роботи 3 підвищення кваліфікації працівників апарату; забезпечувати організацію діловодства в суді, порядок у роботі з процесуальними та іншими документами, функціонування локальної комп'ютерної мережі, мережі «Інтернет», електронної пошти, функціонування систем фіксування судового процесу технічними засобами, оперативного ведення інформаційно-довідкових стендів; забезпечувати функціонування автоматизованої системи документообігу суду, здійснювати контроль за ії використанням; уживати заходів щодо зберігання та конфіденційності інформації, яка міститься в системі; підписувати протоколи автоматичного розподілу справ між суддями й у разі необхідності забезпечувати повторний автоматичний розподіл справ між суддями [5]. Крім того, керівник апарату суду зобов'язаний здійснювати такі дії: уживати заходів щодо забезпечення захисту інформаційних ресурсів системи автоматизованого документообігу шляхом застосування засобів і методів технічного захисту інформації, упровадження організаційних та інженерно-технічних заходів комплексної системи захисту інформації, спрямованих на недопущення блокування інформації, несанкціонованого доступу до неї, її модифікації або спотворення; забезпечувати дотримання в суді встановленого порядку обліку, зберігання і використання документів, справ, видань та інших матеріальних носіїв інформації, що містять конфіденційну інформацію, яка $є$ власністю держави, а також інформації та персональних даних про особу; забезпечувати достовірність ведення судової статистики та контролювати своєчасність складання статистичної звітності; організовувати роботу з обліку і збереження судових справ, печаток і штампів, канцелярського приладдя; контролювати своєчасність відправлення справ і додаткових матеріалів; забезпечувати направлення до Єдиного державного реєстру копій судових рішень; забезпечувати організацію повного доступу суддів до Єдиного державного реєстру судових рішень; організовувати доступ користувачів до Єдиного державного реєстру юридичних осіб та фізичних осіб-підприємців і контроль за дотриманням вимог щодо захисту інформації; організовувати складання проєктів планів роботи суду, подавати їх на затвердження голові суду, організовувати контроль за ходом виконання цих планів; здійснювати заходи щодо забезпечення 
належних умов діяльності суддів і працівників апарату, їх належного матеріального та соціального забезпечення, медичного обслуговування, забезпечення житлом; організовувати виконання вимог актів законодавства, нормативних актів щодо забезпечення безпеки суддів, працівників апарату суду, учасників судового процесу, підтримання громадського порядку в приміщенні суду та його охорони; організовувати виконання передбачених законодавством заходів щодо запобігання та протидії корупції [5]. Для здійснення покладених на нього завдань та обов'язків керівник апарату суду має право здійснювати такі дії: видавати накази, обов'язкові для виконання працівниками апарату; координувати здійснення організаційних заходів щодо підготовки нарад; проводити наради; призначати на посади та звільняти з посад в установленому законом порядку працівників апарату; застосовувати заохочення та накладати дисциплінарні стягнення; контролювати роботу служби судових розпорядників; контролювати виконання посадових обов'язків, закріплених посадовими інструкціями, дотримання в суді норм, правил та інструкцій з охорони праці й пожежної безпеки, правил внутрішнього трудового розпорядку, що діють у суді, вимог, передбачених колективним договором і чинним законодавством [5].

Отже, адміністративно-правовий статус керівника апарату суду - це сукупність його повноважень, зобов'язань, прав та обов'язків щодо організації забезпечення суддям умов для здійснення судочинства, організації матеріальних, технічних, охоронних та інших забезпечувальних функцій у суді.

Найбільш тісно із суддями працюють помічник судді, секретар судового засідання, судовий виконавець. Саме вони забезпечують законні потреби суддів у здійсненні судочинства. Адміністративно-правовий статус помічника судді визначається Законом України «Про судоустрій і статус суддів», Положенням про помічника судді, затвердженим Рішенням Ради суддів України від 18.05.2018 р. № 21 [6]. Помічник судді - це працівник патронатної служби у суді, який забезпечує виконання суддею повноважень щодо здійснення правосуддя. Помічник судді є працівником апарату суду. Помічник судді з питань підготовки та організаційного забезпечення судового процесу підзвітний лише відповідному судді. Суддя є його безпосереднім керівником. Помічником судді може бути громадянин України, який має вищу юридичну освіту і вільно володіє державною мовою. Помічники суддів Верховного Суду повинні також мати стаж професійної діяльності у сфері права не менше трьох років. Судді самостійно здійснюють добір помічників. Помічник судді призначається на посаду та звільняється з посади керівником апарату відповідного суду за поданням судді. Помічник судді призначається на посаду на строк повноважень без- посереднього керівника та не довше від періоду перебування безпосереднього керівника у штаті суду.

Помічник судді має такі права: користуватись правами і свободами, які гарантуються громадянам України Конституцією і законами України; отримувати від працівників апарату суду, до якого він прикріплений, документи та інформацію, необхідні для виконання своїх обов'язків; користуватися інформаційними базами даних, телекомунікаційними мережами відповідного суду в установленому порядку; вносити пропозиції судді щодо організації своєї роботи; за погодженням із суддею брати участь у конференціях, семінарах, круглих столах, форумах, інших науково-практичних заходах, а за поданням судді він може проходити стажування у відповідних підрозділах державних органів; брати участь у нарадах, зборах трудового колективу та інших подібних заходах відповідного суду; підвищувати свій професійний рівень у системі підготовки та підвищення кваліфікації працівників апарату суду; на повагу особистої гідності, справедливе і шанобливе ставлення до себе з боку керівників, співробітників і громадян; на оплату праці відповідно до чинного законодавства; на соціальний і правовий захист відповідно до свого статусу [6].

Отже, основними завданнями помічника судді $\epsilon$ допоміжні й забезпечувальні заходи, які необхідні для підготовки й розгляду судової справи, технічні заходи щодо вироблення і виконання судових рішень.

Адміністративно-правовий статус помічника судді - це сукупність його повноважень, завдань, зобов' язань і прав щодо допомоги судді в підготовці судових справ до розгляду, виконання інших законних доручень судді і керівника апарату суду в поєднанні з професійними обмеженнями та спеціальною дисциплінарною відповідальністю.

Секретар судового засідання є посадовою особою апарату суду. Його адміністративно-правовий статус визначається Конституцією та законами України «Про судоустрій і статус суддів», «Про державну службу», процесуальними нормами відповідного судочинства, положеннями про апарат відповідного суду, Положенням про автоматизовану систему документообігу суду, Загальними правилами поведінки державного службовця, кодексом поведінки посадової особи апарату відповідного суду, регламентом відповідного суду, інструкцією з діловодства у відповідному суді, наказами і розпорядженнями голови відповідного суду та керівника апарату суду. Секретар судового засідання за своїми посадовими обов'язками є взаємозамінним з судовим розпорядником. Секретар судового засідання призначається на посаду і звільняється з неї наказом керівника апарату адміністративного суду. На посаду секретаря судового засідання призначаються особи, які мають вищу юридичну 
освіту за спеціальностями «Правознавство», «Правоохоронна діяльність» 3 освітньо-кваліфікаційним рівнем не нижче бакалавра, зі стажем роботи за фахом на державній службі в органах судової влади не менше 2 років або стажем роботи за фахом в інших сферах не менше 3 років. Секретар судового засідання підпорядкований голові апарату відповідного суду [1]. Секретар судового засідання зобов'язаний здійснювати такі дії: вживати необхідних заходів щодо дотримання процесуальним законодавством процесуальних термінів розсилання прийнятих в адміністративних справах копій процесуальних документів; передавати суддям документи у справах, які перебувають у їх провадженні; перевіряти наявність і належність оформлення всіх необхідних документів у справах, переданих для відправлення після закінчення розгляду, зокрема кількість копій процесуальних документів, необхідних для завірення та відправлення, у разі відсутності певних документів чи їх копій звертатися до відповідного помічника судді; підшивати та оформлювати матеріали справ згідно з інструкцією 3 діловодства; за дорученням судді ознайомлювати сторони зі справою відповідно до інструкції з діловодства в суді; фіксувати судовий процес технічними засобами, вести журнал судового засідання; відтворювати та роздруковувати технічні записи судових засідань у встановленому законом порядку; здійснювати судові виклики й повідомлення; перевіряти наявність і з'ясовувати причину відсутності осіб, яких було викликано до суду, доповідати про це голові; виконувати інші доручення голови у справі; здійснювати необхідну технічну роботу з відправлення копій процесуальних документів адміністративних справ та іншої кореспонденції; забезпечувати належне використання та зберігання документів, судових справ, а також печаток і штампів суду [7].

Отже, адміністративно-правовий статус секретаря судового засідання складається з його правосуб'єктності, зобов'язань і прав щодо забезпечення судді шляхом розсилання копій процесуальних документів, перевірки наявності та належності оформлення всіх необхідних документів у справах, здійснення технічного фіксування судового процесу, ведення журналу судового засідання, перевірки наявності та з'ясування причин відсутності осіб, яких було викликано до суду, тощо у сукупності зі спеціальною дисциплінарною відповідальністю за порушення трудової дисципліни, за неякісне або несвоєчасне виконання посадових завдань та обов'язків, за бездіяльність або невикористання наданих йому прав, за порушення норм етики поведінки державного службовця та обмежень, пов'язаних із прийняттям на державну службу та ії̈ проходженням.

Висновки. Отже, правовий статус працівників апарату суду не повинен обмежуватися лише пе- реліком їх прав та обов'язків, оскільки це призводить до неповного розкриття його змісту. Так само не вважаємо за доцільне штучно розширювати перелік структурних елементів правового статусу. Визначити і розкрити усі елементи правового статусу працівника апарату суду лише за допомогою спеціального Закону України «Про судоустрій і статус суддів» неможливо. Зміни у законодавстві не змінили той факт, що у штаті апарату суду значна кількість посад залишає за собою статус державної служби, тому ми змушені застосовувати Закон України «Про державну службу», а також підзаконні і локальні правові акти судів під час правового визначення статусу працівника апарату суду, адже цим Законом визначаються вимоги до осіб, які мають право на державну службу, основні обов'язки та права державних службовців, встановлюються обмеження, пов'язані з прийняттям на державну службу, особливості прийняття на державну службу та дисциплінарної відповідальності державних службовців, питання службової кар'єри та припинення державної служби.

\section{Jimepamypa}

1. Юрченко Ю.В Адміністративно-правове регулювання у сфері судочинства. Правознавство. Випускний курс. Київ : Університет «Україна», 2013. 296 с.

2. Про судоустрій і статус суддів : Закон України від 02.06.2016 p. URL: https://zakon.rada.gov.ua/laws/ show/1402-19.

3. Про державну службу : Закон України від 10.12. 2015 p. URL: https://zakon.rada.gov.ua/laws/ show/889-19.

4. Організація роботи суду : навч. посіб. / I.Є. Марочкін, Л.М. Москвич, О.М. Овчаренко та ін. ; за заг. ред. І.Є. Марочкіна. Харків : Право, 2012. 256 с.

5. Типове положення про апарат суду : Наказ Державної судової адміністрації України від 08.02.2019 p. № 131. URL: https://zakon.rada.gov.ua/ rada/show/v0131750-19.

6. Положення про помічника судді : Рішення Ради суддів України від 18.05.2018 р. № 21. URL: https://zakon.rada.gov.ua/rada/show/vr021414-18.

7. Типова посадова інструкція секретаря судового засідання місцевого загального суду : Наказ Державної судової адміністрації України від 20.07.2005 p. № 86. URL: https://ifm.if.court.gov.ua/ sud0907/vakansii/c_z/.

\section{Анотація}

Шевченко $A$. В. Правовий статус працівників апарату суду. - Стаття.

У науковій статті аналізуються положення чинного законодавства в частині реалізації закріплених Конституцією України та Законом України «Про державну службу» положень, що стосуються визначення статусу працівників апарату суду. Розглядаються положення нового та перспективного законодавства про державну службу, положення Закону України «Про судоустрій і статус суддів» у контексті урегульованості та визначеності статусу працівників апарату суду. Досліджено особливості організації роботи, підпорядкування та фінансової забезпеченості працівників апарату суду. 
Адміністративно-правовий статус керівника апарату суду - це сукупність його повноважень, зобов'язань, прав та обов' язків щодо організації забезпечення суддям умов для здійснення судочинства, організації матеріальних, технічних, охоронних та інших забезпечувальних функцій у суді. Адміністративно-правовий статус помічника судді - це сукупність його повноважень, завдань, зобов'язань і прав щодо допомоги судді в підготовці судових справ до розгляду, виконання інших законних доручень судді і керівника апарату суду в поєднанні з професійними обмеженнями та спеціальною дисциплінарною відповідальністю.

Правовий статус державного службовця в судовій системі розглядається як сукупність встановлених законодавчими нормами функцій, повноважень, прав і обов'язків, правових обмежень, етичних стандартів в сукупності з підставами, порядком виникнення їхньої службової правосуб'єктності та юридичної відповідальності в аналізованій сфері. Важливість зазначеної проблеми зумовлена тим, що на державних службовців судової системи покладено низку зобов'язань у сфері державної політики, основна мета яких - забезпечення справедливості, а саме правового захисту прав, свобод і законних інтересів фізичних і юридичних осіб, адже боротьба за справедливість нині відбувається майже в усіх основоположних сферах життедіяльності суспільства. Запобігання порушенням і припинення порушень прав і свобод громадян, а також їх відновлення є важливим актуальним чинником, який допоможе у формуванні правової свідомості громадян.

Ключові слова: судова влада, працівник апарату суду, судовий розпорядник, помічник судді, державна служба, судова реформа.

\section{Summary}

Shevchenko A. V. The legal status of the court apparatus staff. - Article.

The scientific article analyzes the provisions of the current legislation in terms of the implementation of the provisions of the Constitution of Ukraine and the current Law of Ukraine "On Civil Service" provisions concerning the determination of the status of employees of the court apparatus. The provisions of the new and promising legislation on the civil service, the provisions of the Law of Ukraine "On Judiciary and the Status of Judges" are considered in the context of the regularity and determination of the status of employees of the court apparatus. The peculiarities of organization of work, subordination and financial security of court staff are investigated.

The administrative and legal status of the head of the court apparatus is a set of his / her powers, obligations, rights and duties to organize the provision of conditions for judges to carry out justice, to organize material, technical, security and other security functions in court.

The administrative and legal status of an assistant judge is the totality of his / her powers, tasks, obligations and rights to assist the judge in the preparation of court cases, the execution of other legal orders of the judge and the head of the court apparatus in combination with professional restrictions and special disciplinary responsibility.

The legal status of a civil servant in the judiciary is regarded as a set of statutory functions, powers, rights and obligations, legal restrictions, ethical standards in conjunction with the grounds and order of their official legal personality, as well as legal responsibility in the analyzed and. The importance of these issues is due to the fact that civil servants of the judicial system are under a number of obligations in the field of public policy, the main purpose of which is to ensure justice, namely the legal protection of the rights, freedoms and legitimate interests of individuals and legal entities, since the fight for justice is taking place now, in almost all fundamental spheres of life of society. Prevention of violations and termination of violations of citizens' rights and freedoms, as well as their restoration is an important relevant factor that will help to shape the legal consciousness of citizens.

Key words: judiciary, court staff, court clerk, assistant judge, civil service, judicial reform. 